\title{
Gatifloxacin: A Comprehensive Review on Analytical Method
}

\section{Pritam S Jain*, Jagruti B Salunke, Ashvini A Navghare and Sanjay J Surana}

R.C. Patel Institute of Pharmaceutical Education and Research, India

*Corresponding Author: Pritam S Jain, R.C. Patel Institute of Pharmaceutical Education and Research, India.

Received: April 08, 2019; Published: May 03, 2019

DOI: $10.31080 /$ ASPS.2019.03.0272

\begin{abstract}
This review focuses on the recent advances in analytical techniques for assessment of Gatifloxacin only or in combinations with other drugs in various biological media. Gatifloxacin is an 8-methoxyfluoroquinolone with improved activity beside Grampositive, anaerobes, and broad-spectrum activity against Gram-negative bacteria. This article investigate that published analytical methods mentioned so far in the literature for the quantification of GA in pharmaceutical preparations and biological fluids. GA accessible single or in combination with added drugs in pharmaceutical matrices with many drugs like Levofloxacin, Moxifloxacin, Dexamethasone, Satranidazole, Difluprednate. They include different techniques similar to High-performance liquid chromatography, Spectrophotometry, electrochemical methods, Spectrofluorometric and High-performance thin layer chromatography. The concise reviews demonstrate the percentage utilization of the different approaches for analysis of GA.
\end{abstract}

Keywords: Gatifloxacin; Review; Analytical Method; Chromatography

\section{Abbreviations}

GA: Gatifloxacin; SAR: Structural Activity Relationship; OZ: Ornidazole; LOM: Lomefloxacin; LEV: Levofloxacin; AM: Ambroxol Hydrochloride; DFP: Difluprednate; SAT: Satranidazole; DNA: Deoxyribonucleic Acids; HPLC: High Performance Liquid Chromatography; RP-HPLC: Reverse Phase High Performance Liquid Chromatography; PRED: Prednisolone Acetate; MOX: Moxifloxacin; TRO: Trovafloxacin; RSD: Relative Standard Deviation; LOD: Limit of Detection; LOQ: Limit of Quantitation.

\section{Introduction}

Gatifloxacin is chemically known as 1-cyclopropyl-6-fluoro8-methoxy-7-(3-methyl piperazin-1yl)-4-oxo-1,4-dihydro-quinoline-3-carboxylic acid. GA is a well know fourth-generation fluoroquinolone. GA has a broad spectrum of activity, with dynamic outstanding activity against atypical organisms and Gram-negative bacteria, as well as activity against Gram-positive bacteria [1]. Gatifloxacin is well absorbed from the gastrointestinal (GI) tract (oral availability approximately $100 \%$ ), and concomitant administration of a continental breakfast, $1050 \mathrm{kcal}$, had no effect on its availability [2]. The standard dose for GA is $400 \mathrm{mg}$ once a day and both oral and IV formulations are available [3,4].

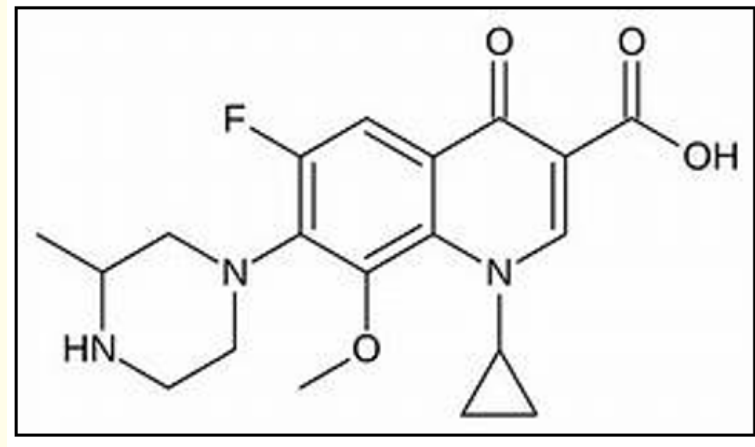

Figure 1: Structure of Gatifloxacin.

Chemistry of gatifloxacin

SAR studies of Gatifloxacin fluoroquinolone (GA) antibacterial entities demonstrated that the basic group at the $\mathrm{C}-7$ position is the most accommodable site for chemical change and an area that considerably affects their potency, spectrum and safety [5]. Pyrrolidinyl and Piperazinyl type side chains have been proven to be the optimal substituent. For example, several of the early fluoroquinolone (ciprofloxacin and ofloxacin), have a Piperazinyl group at the C-7 position, and introduction of the noted pyrrolidine derivatives to 
the fluoroquinolones (moxifloxacin and trovafloxacin) resulted in a dramatic advancement of Gram-positive activity [6,7]. Fluoroquinolones act by obstructing two enzymes involved in bacterial DNA synthesis, both of which are DNA topoisomerases that human cells lack and that are essential for DNA replication of bacteria, thereby allowing these agents to be both bactericidal and specific.

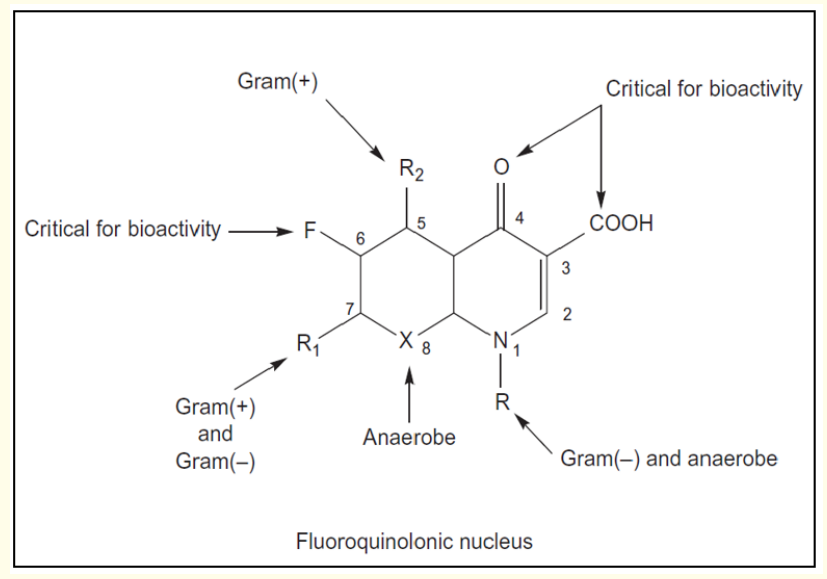

Figure 2: Structure activity relationships in the fluoroquinolone nucleus.

\section{Pharmacokinetic properties}

The Gatifloxacin drug has high oral bioavailability about 96\%, and hence, intravenous and oral formulations are inter-changeable and bioequivalent. GA has a low protein binding ( $20 \%)$, large volume of distribution $\left(\sim 1.8 \mathrm{~L} \mathrm{~kg}^{-1}\right)$ and broad tissue distribution and is primarily excreted unchanged in the urine (180\%). The drug has high oral bioavailability near about $96 \%$ and therefore, intravenous and oral formulations are interchangeable and bioequivalent. Gatifloxacin has a low protein binding ( $\sim 20 \%)$, large volume of distribution $(\sim 1.8 \mathrm{~L} / \mathrm{kg})$, and broad tissue distribution and is primarily excreted unchanged in the urine (180\%) [8].

\section{Pharmacodynamic properties}

GA be able to administered externally dose modification in patients with hepatic impairment, in women and in the elderly. Clinical studies and in-vitro experiments designate that GA does not associate with drugs metabolized by the cytochrome P450 enzyme family. At therapeutically valid doses, Gatifloxacin is pharmacodynamically linked parameters (the ratio of the AUC to minimum inhibitory concentration and the ratio of Max. serum concentration to Mini. inhibitory concentration) are near to each other or better than those of other fluoroquinolones. Clinical studies indicate that
Gatifloxacin has insufficient potential to prolong the QT interval on the electrocardiogram and lacks the potential to cause crystaluria as well as produce photosensitivity reactions, make alteration to oral glucose tolerance [8].

\section{Analytical method}

The substantial literature survey exposed that, many analytical methods have been discover for validation and development of analytical methods for identification and quantification of drugs and other molecules of interest in Pharmaceutical Matrices. More analytical methods were ornamented for the determination of Gatifloxacin in biological fluids and in pharmaceutical formulations. Such as HPLC, RP-HPLC, UV Visible spectroscopy, Spectrofluoromery, absorption ratio method and electrochemical method, has been developed. Methods such as HPLC, electrochemical analysis and simultaneous UV spectroscopic methods of Gatifloxacin are reported for estimation of Gatifloxacin alone or in combination with others Levofloxacin, Moxifloxacin, Dexamethasone, Satranidazole, Difluprednate, and Difluprednate.

\section{Bioanalytical method}

The development of a reliable bioanalytical methods are of predominant importance throughout the duration of drug discovery and development, culminating in a marketing approval. Bioanalysis, employed for the quantitative estimation of drugs entities as well as their metabolites into biological fluids, plays a important role in the interpretation and evaluation of PK, toxic kinetic studies and bioequivalence [9].

\section{HPLC}

High performance liquid chromatography was developed early in the year 1960. HPLC is a type of liquid chromatography method, where separation occurs between a stationary phase and a mobile phase. Separation is depends upon the nature of the stationary phase, the separation process can be of four different modes: partition chromatography, ion-exchange chromatography, adsorption chromatography, and size exclusion chromatography. It is an instrumental analytical method that gained increased acceptance mainly because it met two basic factors: (a) the need for methods that can be simply mechanical, and (b) the need for a wide range of accelerated analysis for nutrients. HPLC method is administered to several categories of substances such as lipids, carbohydrates, vitamins, synthetic colorings, additives, natural pigments, and amino, acids contaminants [10]. Estimation of Gatifloxacin in single or in combination with added drugs in biological fluid and pharmaceutical matrices by HPLC are note down in Table 1. 


\begin{tabular}{|c|c|c|c|c|c|c|c|c|c|c|}
\hline $\begin{array}{l}\text { Sr. } \\
\text { No }\end{array}$ & Drugs & Matrix & Column & $\begin{array}{l}\text { Mobile } \\
\text { phase }\end{array}$ & Detector & $\begin{array}{c}\text { Lambda } \\
\text { Max }\end{array}$ & Linearity & $\begin{array}{l}\text { LOD and } \\
\text { LOQ }\end{array}$ & $\begin{array}{c}\text { System } \\
\text { suitability }\end{array}$ & Ref \\
\hline 1 & GA & $\begin{array}{l}\text { Bulk drug } \\
\text { and pceu- } \\
\text { tical prepa- } \\
\text { rations }\end{array}$ & $\begin{array}{c}\text { RP SUPE- } \\
\text { LCO® } 516 \\
\mathrm{C}_{18} \mathrm{DB}, \\
50306-\mathrm{U}, \\
\text { column }\end{array}$ & $\begin{array}{l}\text { disodium } \\
\text { hydrogen } \\
\text { phosphate } \\
\text { buffer: } \\
\text { acetonitrile } \\
(75: 25, \mathrm{v} / \mathrm{v})\end{array}$ & 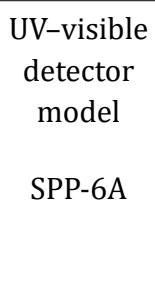 & $293 \mathrm{~nm}$ & $\begin{array}{c}4.0-40 \mu \mathrm{g} / \\
\mathrm{mL}\end{array}$ & $\begin{array}{c}\text { LOD - } 6.507 \\
\mu \mathrm{g} / \mathrm{mL} \\
\text { LOQ- } 1.538 \\
\mu \mathrm{g} / \mathrm{mL}\end{array}$ & $\begin{array}{c}\text { RT- } \\
2.767 \mathrm{~min}\end{array}$ & [11] \\
\hline 2 & $\begin{array}{l}\text { GAT } \\
\text { SAT }\end{array}$ & $\begin{array}{l}\text { Bulk and } \\
\text { Tablet }\end{array}$ & $\begin{array}{l}\text { RP Lichro- } \\
\text { spher } 100 \mathrm{C}_{18}\end{array}$ & $\begin{array}{l}\text { Water: Ace- } \\
\text { tonitrile: } \\
\text { Triethyl- } \\
\text { amine } \\
(75: 25: \\
0.35, \mathrm{v} / \mathrm{v} / \mathrm{v})\end{array}$ & $\begin{array}{l}\text { Hitachi L } \\
\text { - } 7420 \mathrm{UV} \\
\text { - Visible } \\
\text { detector }\end{array}$ & $320 \mathrm{~nm}$ & $1-70 \mu \mathrm{g} / \mathrm{mL}$ & $\begin{array}{c}\text { LOD- } \\
0.5 \mu \mathrm{g} / \mathrm{mL} \\
0.803 \mathrm{ug} / \\
\mathrm{ml} \\
\\
\text { LOQ- } 1.0 \\
\mu \mathrm{g} / \mathrm{mL} \\
2.411 \mathrm{ugml}\end{array}$ & $\begin{array}{c}\text { RT- } \\
6 \text { min } \\
\text { TP- } \\
3725.8 \\
\text { TF - } \\
1.66\end{array}$ & [12] \\
\hline 3 & GA & Pure form & $\begin{array}{l}\text { RP Stain- } \\
\text { less steel } \mathrm{C}_{18} \\
\text { column }\end{array}$ & $\begin{array}{l}\text { Buffer: ace- } \\
\text { tonitrile (80: } \\
20)\end{array}$ & $\begin{array}{c}\text { UV/VIS } \\
\text { detector } \\
\text { model } \\
1575\end{array}$ & $210 \mathrm{~nm}$ & $\begin{array}{c}10-50 \mu \mathrm{g} / \\
\mathrm{mL}\end{array}$ & $\begin{array}{c}\text { LOD- } \\
6.5 \mu \mathrm{g} / \mathrm{mL} \\
\text { LOQ- } \\
21.33 \mu \mathrm{g} / \\
\mathrm{mL}\end{array}$ & $\begin{array}{c}\text { RT- } \\
1085 \text { min } \\
\text { TP - } 7271\end{array}$ & [13] \\
\hline 4 & $\begin{array}{l}\text { GA } \\
\text { DFP }\end{array}$ & $\begin{array}{c}\text { Bulk and } \\
\text { Tablet }\end{array}$ & $\begin{array}{l}\mathrm{C}_{18} \text { column } \\
(250 \mathrm{~mm} \mathrm{x} \\
4.6 \mathrm{~mm}, 5 \mu)\end{array}$ & $\begin{array}{c}\text { Methanol: } \\
\text { 0.01M } \\
\text { Disodium } \\
\text { hydrogen } \\
\text { phosphate } \\
(60: 40 \mathrm{v} / \mathrm{v})\end{array}$ & $\begin{array}{c}\text { PDA } \\
\text { detector }\end{array}$ & $242 \mathrm{~nm}$ & $\begin{array}{l}60-360 \\
\mu \mathrm{g} / \mathrm{mL}\end{array}$ & $\begin{array}{c}\text { LOD -6.5 } \\
\mu \mathrm{g} / \mathrm{mL}- \\
\text { LOQ- } 21.33 \\
\mu \mathrm{g} / \mathrm{mL}\end{array}$ & $\begin{array}{l}\text { RT- } \\
3.01\end{array}$ & [14] \\
\hline 5 & GA & $\begin{array}{l}\text { Pure form } \\
\text { and } \\
\text { Ophthal- } \\
\text { mic Soluti- } \\
\text { on }\end{array}$ & $\begin{array}{l}\text { RP HPLC In- } \\
\text { ertsil } C_{18} \\
\text { column }\end{array}$ & $\begin{array}{l}0.1 \text { M sodium } \\
\text { dihydrogen } \\
\text { phosphate } \\
\text { Buffer: ace- } \\
\text { tonitrile }(70 \text { : } \\
30 \mathrm{v} / \mathrm{v})\end{array}$ & $\begin{array}{l}\text { PDA de- } \\
\text { tector }\end{array}$ & $254 \mathrm{~nm}$ & $\begin{array}{c}25-150 \mu \mathrm{g} / \\
\mathrm{mL}\end{array}$ & $\begin{array}{c}\text { LOD -1.2 } \\
\mu \mathrm{g} / \mathrm{mL} \\
\text { LOQ- } 2.8 \\
\mu \mathrm{g} / \mathrm{mL}\end{array}$ & $\begin{array}{c}\text { TF- } 1.23 \\
\text { TP-2605.79 }\end{array}$ & [15] \\
\hline 6 & $\begin{array}{c}\text { GA and } \\
\text { AM } \\
\text { Tablet }\end{array}$ & $\begin{array}{l}\text { Tablet dos- } \\
\text { age forms }\end{array}$ & $\begin{array}{l}\text { RP HiQ Sil } C_{18} \\
\text { column }\end{array}$ & $\begin{array}{c}\text { Potassium } \\
\text { dihydrogen } \\
\text { orthophos- } \\
\text { phate buffer } \\
\text { and acetoni- } \\
\text { trile }(70: 30 \text {, } \\
\text { v/v) }\end{array}$ & $\begin{array}{l}\text { UV-2075 } \\
\text { variable } \\
\text { wave- } \\
\text { length } \\
\text { detector }\end{array}$ & $247 \mathrm{~nm}$ & $\begin{array}{l}\text { GA- } 10-60 \\
\mu \mathrm{g} / \mathrm{mL} \mathrm{AM}- \\
5-30 \mu \mathrm{g} / \mathrm{mL}\end{array}$ & $\begin{array}{c}\text { GA- } \\
\text { LOD- } \\
0.3 \mu \mathrm{g} / \mathrm{mL} \\
\text { LOQ- } \\
0.5 \mu \mathrm{g} / \mathrm{mL}\end{array}$ & - & [16] \\
\hline
\end{tabular}




\begin{tabular}{|c|c|c|c|c|c|c|c|c|c|c|}
\hline 7 & $\begin{array}{l}\text { GA, LEV, } \\
\text { LOM }\end{array}$ & Bulk drug & $\begin{array}{c}\text { LiChro- } \\
\text { spher }^{\circledR} 100 \\
\text { RP-C }_{18} \\
\text { column }\end{array}$ & $\begin{array}{c}\text { Water: } \\
\text { Acetonitrile } \\
(80: 20, \mathrm{v} / \mathrm{v})\end{array}$ & $\begin{array}{l}\text { UV detec- } \\
\text { tor }\end{array}$ & $\begin{array}{c}179-295 \\
\mathrm{~nm}\end{array}$ & $\begin{array}{c}4.0 \text { to } 24.0 \\
\mu \mathrm{g} / \mathrm{mL}\end{array}$ & $\begin{array}{l}\text { GA- } \\
\text { LOD- } \\
0.13 \mu \mathrm{g} / \\
\mathrm{mL} \\
\text { LOQ- } \\
0.39 \mu \mathrm{g} / \mathrm{mL}\end{array}$ & $\begin{array}{c}\text { GA- } \quad \text { RT- } \\
4.14 \\
\text { LEV- } \\
\text { RT- } 2.37 \\
\text { LOM- RT- } \\
2.81\end{array}$ & [17] \\
\hline 8 & GA & Tablet & $\begin{array}{c}\text { RP X terra } \\
\mathrm{C}_{18} \text { column } \\
(4.6 \mathrm{~mm} 150 \\
\mathrm{mm})\end{array}$ & $\begin{array}{c}\text { Buffer: aceto- } \\
\text { nitrile }(60: 40 \\
\text { v/v) }\end{array}$ & $\begin{array}{c}\text { Dual } \\
\text { lambda } \\
\text { absor- } \\
\text { bance } \\
\text { uv-visible } \\
\text { detector }\end{array}$ & $298 \mathrm{~nm}$ & $\begin{array}{c}0.01 \text { to } 0.50 \\
\mu \mathrm{g} / \mathrm{ml}\end{array}$ & $\begin{array}{c}\text { LOD- } \\
0.13 \mu \mathrm{g} / \mathrm{mL} \\
\text { LOQ- } \\
0.39 \mu \mathrm{g} / \\
\mathrm{mL}\end{array}$ & $\begin{array}{c}\text { RT- } 2.34 \\
\text { TF- } 0.5123 \\
\text { TP- } 10012\end{array}$ & [18] \\
\hline 9 & $\begin{array}{l}\text { GA, } \\
\mathrm{OZ}\end{array}$ & Tablet & $\mathrm{C}_{18}$ column & $\begin{array}{c}\text { Acetonitrile: } \\
0.025 \mathrm{M} \\
\text { Potassium } \\
\text { dihydrogen- } \\
\text { phosphate } \\
\text { buffer (50:50 } \\
\text { v/v) }\end{array}$ & $\begin{array}{l}\text { UV Detec- } \\
\text { tor }\end{array}$ & $300 \mathrm{~nm}$ & $2-24 \mu \mathrm{g} / \mathrm{mL}$ & $\begin{array}{c}\text { LOD } \\
-0.0004 \\
\mu \mathrm{g} / \mathrm{mL} \\
\text { LOQ- } \\
0.0012 \\
\mu \mathrm{g} / \mathrm{mL}\end{array}$ & $\begin{array}{l}\text { RT- } 2.89 \\
\text { min } \\
\text { TF- } 1.25 \\
\text { TP- } \\
37108.8\end{array}$ & [19] \\
\hline 10 & $\begin{array}{c}\text { GA } \\
\text { Keto-lac } \\
\text { Trometh- } \\
\text { am-ine }\end{array}$ & Pure form & $\begin{array}{l}\text { RP BDS } \\
\text { Hypersil } \\
\text { C8 column } \\
(250 \times 4.6 \\
\mathrm{mm})\end{array}$ & $\begin{array}{c}\text { Methanol: } \\
\text { Phosphate } \\
\text { buffer (pH } \\
3.0)(55: 45 \\
\text { v/v) }\end{array}$ & $\begin{array}{l}\text { UV detec- } \\
\text { tor. }\end{array}$ & $270 \mathrm{~nm}$ & $\begin{array}{l}\text { GA- } \quad 30- \\
90 \mu \mathrm{g} / \mathrm{mL} \\
\text { Ketorolac } \\
\text { Trometham- } \\
\text { ine- } \\
\begin{array}{c}50-110 \mu \mathrm{g} / \\
\mathrm{mL}\end{array}\end{array}$ & - & - & [20] \\
\hline 11 & $\begin{array}{l}\text { GA and } \\
\text { Dexamet- } \\
\text { hason }\end{array}$ & Pure form & $\begin{array}{c}\text { Hypersil } \\
C_{8} \text { column } \\
(0.250 \mathrm{~m} \mathrm{X} \\
4.6 \mathrm{~mm})\end{array}$ & $\begin{array}{c}0.02 \text { M phos- } \\
\text { phate buffer: } \\
\text { Methanol } \\
(42: 58 \mathrm{v} / \mathrm{v})\end{array}$ & $\begin{array}{c}\text { DAD } \\
\text { Detector. }\end{array}$ & $270 \mathrm{~nm}$ & $\begin{array}{l}\text { GA- } \\
0.000040- \\
0.000280 \\
\mathrm{~mol} / \mathrm{L}\end{array}$ & - & $\begin{array}{c}\begin{array}{c}\text { RT- } 3.38 \\
\text { min }\end{array} \\
\text { TF- } 1.41 \\
\text { TP- } 4588\end{array}$ & {$[21]$} \\
\hline
\end{tabular}

Table 1: HPLC analytical determination of GA.

\section{Analytical determination of Gatifloxacin}

Ibrahim A. Aljuffali., et al. (2014) proposed a quantitative determination of Gatifloxacin into solid lipid nanoparticles (SLNs), eye-drops and tablets employing a very rapid and easy chromatographic technique was developed and validated. Formulations were analyzed using a reverse phase SUPELCO ${ }^{\circledR} 516 \mathrm{C}_{18}$-DB, 50306U, HPLC column ( $250 \mathrm{~mm} \times 4.6 \mathrm{~mm}, 5 \mu \mathrm{m})$ and a mobile phase consisting of acetonitrile: disodium hydrogen phosphate buffer (25:75, $\mathrm{v} / \mathrm{v}$ ) and with orthophosphoric acid $\mathrm{pH}$ was make up to 3.3. The analyte flow rate was adjusted to $1 \mathrm{~mL} \mathrm{~min}^{-1}$ and analyte concentra- 
tions were estimated with the help of UV- visible detector at 293 $\mathrm{nm}$ wavelength. The analysis was carried out at room temperature (RT- $25 \pm 2^{\circ} \mathrm{C}$ ). Gatifloxacin was parted from all the formulations within $2.767 \mathrm{~min}$. There were linear calibration curves over a concentration range of 4-40 $\mu \mathrm{g} \mathrm{mL}^{-1}$ as well as correlation coefficients i.e. R2 was found to be 0.9998 with an average recovery more than 99.91\%. Detection of analyte from different formulations at the similar Rt indicates the specificity and stability of the developed method [11].

N. J. Shah., et al. (2009) proposed a easy, accurate, precise as well as precise reverse phase high performance liquid chromatographic method has been developed and validated for the determination of Gatifloxacin and Satranidazole simultaneously into combined dosage forms. A Lichrospher $100 \mathrm{C} 18$ and having mobile phase of Triethylamine: Acetonitrile: Water (0.35: 25: 75, v/v/v) were utilised for separation. $\mathrm{pH}$ was accustomed up to $3.2 \pm 0.02$ with $10 \% \mathrm{v} / \mathrm{v}$ o-phosphoric acid. Measurements were made at the effluent flow rate of $1.0 \mathrm{~mL}$ min-1through injection quantity up to $20 \mu \mathrm{l}$ and ultraviolet (UV) detection was carried out at $320 \mathrm{~nm}$, as in cooperation components shows logical good response at this wavelength. The retention times (Rt) of Gatifloxacin and Satranidazole were $3.44 \mathrm{~min}$ and $6.0 \mathrm{~min}$, respectively. The planned method was validated in appearance of linearity, precision, accuracy, specificity and robustness. Linearity of Gatifloxacin as well as Satranidazole was established to be in the range of $1-70 \mu \mathrm{g} / \mathrm{mL}$ and $1-70 \mu \mathrm{g} / \mathrm{mL}$, correspondingly. Average proportion recoveries obtained for Satranidazole and Gatifloxacin were $99.80 \%$ and $100.20 \%$, correspondingly. The limit of detection and limit of quantification were originate to be 0.3 and $1.0 \mathrm{mg} / \mathrm{mL}$ for Satranidazole, correspondingly and for Gatifloxacin were 0.5 and $1.0 \mathrm{mg} / \mathrm{mL}$, correspondingly. The process is helpful in the quality control of bulk manufacturing as well as pharmaceutical dosage forms [12].

Ankit Agarwal., et al. (2013) initiated an easy, hasty accurate HPLC process for instantaneous quantitative assessment of Dexamethasone and Gatifloxacin in ophthalmic solution. Chromatographic separation was implemented with PDA detector utilizing Inertsil $C_{18^{\prime}}(250 \times 4.6 \mathrm{~mm}, 5 \mu)$ reverse phase analytical column. The mobile phase consists of Acetonitrile: Buffer (30: $70 \mathrm{v} / \mathrm{v}$ ), was introduced through the column at flow rate (Rt) of $1.0 \mathrm{~mL} / \mathrm{min}$. The method was executed at wavelength $254 \mathrm{~nm}$. The testing was carried out at $30 \mathrm{oC}$. The calibration curve was linear acrossed the concentration series of $25 \%-150 \%$ of the functioning concentration. The lower limit of quantification (LOQ) was found to be $2.8 \mu \mathrm{g} / \mathrm{mL}$ for Gatifloxacin and $1.6 \mu \mathrm{g} / \mathrm{mL}$ for Dexamethasone. The accuracy was found to be in the range (i.e. 98\% - 102\%) for both Gatifloxacin as well as Dexamethasone. Developed method was utilized for simultaneous quantitative determination of Dexamethasone and Gatifloxacin in ophthalmic formulations and method was validated as per ICH guidelines and most valuable for industrial scale as well as academic [15].

Shahed Mirza., et al. (2008)initiated a reversed-phase high performance liquid chromatography (RP-HPLC) analytical technique was developed as well as validated intended for quantification of GA and AM, starting its tablet formulations. The chromatographic separation was achieved through utilizing a HiQ Sil $\mathrm{C}_{18}$ column (250 $\mathrm{mm} \times 4.6 \mathrm{~mm}, 5 \mu \mathrm{m}$ ), through a mobile phase having a blend of $0.01 \mathrm{~mol} \mathrm{~L}^{-1}$ Potassium dihydrogen ortho phosphate buffer (PDP) and Acetonitrile (70:30, v/v), and pH accustomed to 3 with orthophosphoric acid, at a flow rate of $1 \mathrm{~mL} / \mathrm{min}$. The technique was performed at wavelength $247 \mathrm{~nm}$. Separation was concluded in a lesser amount of $10 \mathrm{~min}$. As for every International Conference on Harmonisation (ICH) guidelines the process was validated for linearity, accuracy, precision, limit of quantitation, limit of detection, and robustness. The linearity of Gatifloxacin was obtained in excess of the series of 10-60 $\mu \mathrm{g} / \mathrm{mL}$ and so as to Ambroxol hydrochloride was found to be $5-30 \mu \mathrm{g} / \mathrm{mL}$ The correlation coefficients (r2) were establish to 0.9996 for Gatifloxacin (GA) along with 0.9992 for Ambroxol hydrochloride (AM). The tablet analysis ( $n=5$ ) were originate to be $99.94 \%$ with $\pm 0.25 \%$ standard deviation (SD) in totalling to $99.98 \%$ with $\pm 0.36 \%$ SD on behalf of GA and AM correspondingly. Percent recovery of GA was found to be $99.92 \%-100.02 \%$ and that of AM was $99.86 \%-100.16 \%$. The assay experimentation shows that the technique is free from intervention of recipients. This demonstrates with the purpose of the residential HPLC technique is trouble-free, linear, precise and accurate, as well as can be conveniently adopted for the schedule quality control analysis of the tablet [16].

\section{Bioanalytical determination of Gatifloxacin}

Leandro Tasso., et al. 2007 instigate involuntary coordination utilizing an on-line solid phase withdrawal and HPLC through fluorimetric detection was developed as well as validated for quantification of Gatifloxacin within rat plasma. The extraction was conceded out by means of $\mathrm{C}_{18}$ cartridges (Bond Elute), through a high extraction yield. Following washing, GA was eluted commencing the cartridge through mobile phase by using $\mathrm{C}_{18}$ HPLC analytical column. The mobile phase having a blend of Phosphoric acid (2.5 $\mathrm{mM}$ ), Acetonitrile, Methanol and Triethylamine (64.8:20:15:0.2, 
$\mathrm{v} / \mathrm{v} / \mathrm{v} / \mathrm{v}$ ) as well as $\mathrm{pH}$ accustomed to 2.8. Every one standard as well as samples solutions were chromatographed at $28^{\circ} \mathrm{C}$. The technique fashioned was selective and linear for drug over the concentrations series between 20 and $600 \mathrm{ngmL}^{-1}$. The recovery series intended for Gatifloxacin was establishing to 95.6 to $99.7 \%$, as well as the limit of quantification (LOQ) was originate as $20 \mathrm{ng} / \mathrm{mL}$. The inter and intraday-assay accurateness were awake to $94.3 \%$. The precision approximately not more than $5.8 \%$ in favour of coefficient of variation. High yield obtained up to $95 \%$. Drug stability within plasma was exposed in freezer at $-20^{\circ} \mathrm{C}$ up to 1 month, following three freeze-thaw cycles and in favour of $24 \mathrm{hrs}$ in the auto-sampler after processing. The assay method has effectively functional to evaluate gatifloxacin plasma concentrations in pharmacokinetic study with rat [23].
Angelo Spadaro., et al. 2015 initiateln order to improve the frequent dosing regimen reported for the commercial aqueous gatifloxacin eye drops, two new ophthalmic mucoadhesive formulations based on high molecular weight sodium hyaluronate were prepared. The pharmacokinetic profiles outlined showed a strong bioavailability increase for Gatifloxacin hyaluronate formulations with respect to aqueous conventional eye drop. Gatifloxacin quantification in aqueous humour of albino rabbits was performed by an extremely simple, rapid, direct, sensitive and specific HPLC-UV method. Separations were obtained on an Adsorbosphere $\mathrm{HS} \mathrm{C}_{18}$ column using $\mathrm{CH} 3 \mathrm{CN}$ and an aqueous solution of $10 \mathrm{mM}$ SDS, 10 $\mathrm{mM}$ TBAA and $25 \mathrm{mM}$ citric acid (pH 2.5) (50:50 v/v). Detection was performed at $293 \mathrm{~nm}$ using a flow rate of $1.0 \mathrm{~mL} / \mathrm{min}$. The developed method fulfils the validation requirements of FDA and EMEA and it is suitable for the pharmacokinetic study in rabbit eye $[24]$.

\begin{tabular}{|c|c|c|c|c|c|c|c|c|c|}
\hline $\begin{array}{l}\text { Sr. } \\
\text { No }\end{array}$ & Drug & Matrix & Column & Mobile phase & Detector & Linearity & $\begin{array}{c}\text { ACC and } \\
\text { Preci }\end{array}$ & LOD \& LOD & Ref \\
\hline 1 & GA & Pure form & $\begin{array}{l}\text { Nucleosil-100 } \\
5 \mathrm{C}_{18} \text { column }\end{array}$ & $\begin{array}{l}\text { Acetonitrile: } 0.1 \\
\text { M phosphoric } \\
\text { acid } \\
(90: 10 \mathrm{~V} / \mathrm{V})\end{array}$ & $\begin{array}{c}\text { Fluoresce- } \\
\text { nce detector }\end{array}$ & $\begin{array}{c}0.025-5.00 \\
\mathrm{mg} \mathrm{L}-1\end{array}$ & $\begin{array}{c}\text { Acc- } \\
102.2 .3 \%\end{array}$ & $\begin{array}{c}\text { LOD-Serum- } \\
0.03 \mathrm{mg} / \mathrm{L} \\
\text { Urine- } 1.7 \mathrm{mg} / \mathrm{L} \\
\\
\text { LOQ- Serum- } \\
0.06 \mathrm{mg} / \mathrm{L} \\
\text { Urine- } 3.5 \mathrm{mg} / \mathrm{L}\end{array}$ & [22] \\
\hline 2 & GA & Pure form & $\begin{array}{l}\text { Bond Elut } \mathrm{C}_{18} \\
(10 \mathrm{~mm} \times 2 \\
\mathrm{mm}) \text { column }\end{array}$ & $\begin{array}{c}2.5 \mathrm{mM} \text { phos- } \\
\text { phoric acid meth- } \\
\text { anol: acetonitrile: } \\
\text { triethylamine } \\
(64.8: 15: 20: 0.2 \\
\mathrm{v} / \mathrm{v} / \mathrm{v} / \mathrm{v})\end{array}$ & $\begin{array}{l}\text { RF-10AXL } \\
\text { detector }\end{array}$ & $\begin{array}{c}20-600 \\
\mathrm{ng} / \mathrm{ml}\end{array}$ & $\begin{array}{c}\text { Accu- } \\
\begin{array}{c}95.6-99.7 \% \\
\text { Price- }\end{array} \\
\text { Intraday- } \\
5.2-5.7 \% \\
\text { Intraday- } \\
4.8-5.8 \%\end{array}$ & LOQ- $20 \mathrm{ng} / \mathrm{ml}$ & [23] \\
\hline 3 & GA & $\begin{array}{l}\text { Mucoad- } \\
\text { hesive } \\
\text { Formula- } \\
\text { tions }\end{array}$ & $\begin{array}{l}\text { Adsorbos- } \\
\text { phere HS C } \\
\text { column }\end{array}$ & $\begin{array}{l}\text { CH3CN:10 mM } \\
\text { sodium dodecyl } \\
\text { sulfate }(50: 50) \\
10 \mathrm{mM} \text { tetrabu- } \\
\text { tylammonium } \\
\text { acetate: } 25 \mathrm{mM} \\
\text { citric acid }(\mathrm{pH} \\
2.5)(50: 50 \mathrm{v} / \mathrm{v}) .\end{array}$ & PDA Detector & $\begin{array}{c}50-3000 \\
n g / m\end{array}$ & $\begin{array}{c}\text { Acc- } \\
\text { 1.4-4.94\% } \\
\text { Price- } \\
\text { Interday- } \\
98.42 \text { to } \\
\text { 99.71\% Intra- } \\
\text { day- } 98.67 \text { to } \\
99.64 \%\end{array}$ & $\begin{array}{c}\text { LOD- } \\
18 \mathrm{ng} / \mathrm{mL} \\
\text { LOQ- } 50 \mathrm{ng} / \mathrm{ml}\end{array}$ & [24] \\
\hline
\end{tabular}




\begin{tabular}{|c|c|c|c|c|c|c|c|c|c|}
\hline & & & & & & & & & 19 \\
\hline 4 & $\begin{array}{c}\text { GA } \\
\text { LEV } \\
\text { MOX } \\
\text { TRO }\end{array}$ & Pure form & $\begin{array}{l}\text { RP LiChroC- } \\
\text { ART® Purosp- } \\
\text { her Star } \mathrm{C}_{18} \\
\text { column }(55 \\
\mathrm{mm} \times 4 \mathrm{~mm}\end{array}$ & $\begin{array}{c}\text { Methanol: } 37 \% \\
\text { hydrochloric acid } \\
(99.5: 0.5, \mathrm{v} / \mathrm{v})\end{array}$ & UV Detector & $\begin{array}{c}\text { GAT } \\
-0.005-5 \\
\mu \mathrm{g} / \mathrm{mL} \mathrm{LEV} \\
-0.02-5 \\
\mu \mathrm{g} / \mathrm{mL} \\
\mathrm{MOX}-0.04- \\
5 \mathrm{~g} / \mathrm{mL}\end{array}$ & \begin{tabular}{|c|} 
Acc- \\
GA- $6.80 \%$ \\
LEV-10.49\% \\
MOX-10.83\% \\
Prici-Inter- \\
day- 98.42 to \\
99.71\% Intra- \\
day- 98.67 to \\
$99.64 \%$
\end{tabular} & $\begin{array}{c}\text { LOD- GA-0.0025 } \\
\text { LEV-0.01 } \\
\text { MOX-0.02 } \mu \mathrm{g} / \\
\mathrm{mL} \\
\text { LOQ- } \\
\text { GA-0.005 } \\
\text { LEV-0.02 } \\
\text { MOX-0.04 } \mu \mathrm{g} / \\
\mathrm{mL}\end{array}$ & {$[25]$} \\
\hline 5 & GA & $\begin{array}{l}\text { Pure form } \\
\text { and Tablet }\end{array}$ & $\begin{array}{l}\text { X-Terra } \mathrm{RP} \mathrm{C}_{18} \\
\text { column }\end{array}$ & $\begin{array}{c}\text { Water:acetonit } \\
\text { rile }(90: 10)\end{array}$ & $\begin{array}{c}\text { DAD and } \\
\text { fluoresce-nce } \\
\text { detector }\end{array}$ & $\begin{array}{c}\text { DAD- } \\
0.02-2.00 \\
\mu \mathrm{g} / \mathrm{mL} \\
\text { Fluoresce- } \\
\text { nce } \\
2 \text { to } 20 \\
\mu \mathrm{g} / \mathrm{mL}\end{array}$ & \begin{tabular}{|c|} 
Acc- \\
DAD- 95\% \\
Fluoresce-nce \\
- 95\% \\
Prici- \\
DAD- 3.4\% $\% \mathrm{~g} /$ \\
mL Fluoresce- \\
nce- $2.8 \% \mu \mathrm{g} /$ \\
$\mathrm{mL}$
\end{tabular} & $\begin{array}{c}\text { DAD- } \\
\text { LOD- } 0.7 \mu \mathrm{g} / \mathrm{mL} \\
\text { LOQ- } \underset{\mathrm{mL}}{0.01 \mu \mathrm{g} /} \\
\text { Fluoresce-nce- } \\
\text { LOD- } 2.3 \mu \mathrm{g} / \mathrm{mL} \\
\text { LOQ- } 0.03 \mu \mathrm{g} /\end{array}$ & [26] \\
\hline 6 & GA & Pure form & $\begin{array}{l}\text { VP-ODS } \mathrm{C}_{18} \\
(250 \mathrm{~mm} \times 4.6 \\
\mathrm{mm}) \text { analytic- } \\
\text { cal column }\end{array}$ & $\begin{array}{l}\text { Triethylamine } \\
\text { phosphate } \\
(1 \%, \text { pH4.30): } \\
\text { Acetonitrile } \\
(13: 87, \mathrm{v} / \mathrm{v})\end{array}$ & $\begin{array}{c}\text { Diode array } \\
\text { detector }\end{array}$ & $\begin{array}{c}5-200 \mathrm{ng} / \\
\mathrm{mL}\end{array}$ & $\begin{array}{l}\text { Accu- } \\
102.0 \\
\text { Prici- } \\
2.3 \%\end{array}$ & LOD- 30 ng/mL & [27] \\
\hline 7 & GA & Pure form & $\begin{array}{l}\text { RP X Terra MS } \\
\text { C18 }(3 \mathrm{~mm} \times 50 \\
\mathrm{mm}) \text { column }\end{array}$ & $\begin{array}{c}0.025 \mathrm{M} \text { disodium } \\
\text { hydrogen phos- } \\
\text { phate: Acetoni- } \\
\text { trile } \\
(80: 20 \mathrm{v} / \mathrm{v})\end{array}$ & $\begin{array}{c}\text { Diode array } \\
\text { detector }\end{array}$ & $\begin{array}{c}0.10-6.0 \\
\mu \mathrm{g} / \mathrm{ml}\end{array}$ & $\begin{array}{c}\text { Accu- } 99- \\
107 \% \\
\text { Prici-In- } \\
\text { tra- } \leq 2.77 \% \\
\text { Inter- } \leq 4.59 \%\end{array}$ & $\begin{array}{c}\text { LOQ- } 0.10 . \mu \mathrm{g} / \\
\mathrm{ml}\end{array}$ & [28] \\
\hline
\end{tabular}

Table 2: HPLC bioanalytical methods for Gatifloxacin.

Spectrophotometric method

A compilation of the new developments in terms of detection, detections systems and detection strategies in Ultraviolet-Visible (UV-Vis) spectrophotometry is presented and discussed. It is shown that this evolution has promoted the use of UV-Vis spectrophotometry as a simple, sensitive, reliable, and low cost technique, that allows the determination of very low concentrations of compounds, and the use of very small amounts of samples [29]. Ultraviolet and Visible absorption spectrophotometry is the technique based on attenuation of electromagnetic radiation measurement by an absorbing substance. The function of a UV-Vis detector is to convert a light signal into an electric signal [30].
In the literature survey total 11 methods were reported for the estimation of GA using spectrophotometry, of which 6 methods are for estimation GA alone, while the others GA in combination with other drug substances. In the literature also, 2 spectrofluorometric methods have been established of GA. Spectrophotometric and spectrofluorometric methods have been presented for the determination of GA alone and in Combinations are note down in Table 3.

Estimation of GA as single entity

K.Venugopal., et al. (2005) Novel, easy and price effective UVspectrophotometric methods were developed for the evaluation of Gatifloxacin in bulk and pharmaceutical formulations. Gatifloxacin 
was analysed at 286nm having $100 \mathrm{mM}$ phosphate buffer ( $\mathrm{pH} 7.4$ ) as well as at $292 \mathrm{~nm}$ having $100 \mathrm{mM}$ hydrochloric acid (pH 1.2). Linearity range was found to be $1-18 \mu \mathrm{g} / \mathrm{mL}$ (regression equation: absorbance $=0.0684 \times$ Concentration in $\mu \mathrm{g} / \mathrm{mL}+0.0050 ; \mathrm{r} 2=$ 0.9998 ) in the phosphate buffer $(\mathrm{pH} 7.4)$ and $1-14 \mu \mathrm{g} / \mathrm{mL}$ (regression equation: absorbance $=0.0864 \times$ Concentration in $\mu \mathrm{g} \mathrm{ml}^{-1}+$ 0.0027; r2 = 0.9999) in hydrochloric acid medium (pH 1.2). The apparent molar absorptivity was found to be $2.62 \times 104 \mathrm{l} \mathrm{mol}^{-1} \mathrm{~cm}^{-1}$ in the phosphate buffer and $3.25 \times 104 \mathrm{l} \mathrm{mol}^{-1} \mathrm{~cm}^{-1}$ in hydrochloric acid media. In cooperation the projected techniques sandell's sensitivity was found to be regarding $0.01 \mu \mathrm{g} \mathrm{cm}^{-2} / 0.001 \mathrm{~A}$. These methods were experienced and validated for different constraints with regards to ICH guiding principle and USP. The quantitation limits were found to be 0.312 and $0.3 \mu \mathrm{g} \mathrm{ml}^{-1}$ in the phosphate buffer and hydrochloric acid medium, respectively. The projected systems were effectively applied for the determination of Gatifloxacin into pharmaceutical formulations (tablets, ophthalmic solution as well as injection). The results recognized that the modus operandi is accurate, precise as well as reproducible (relative standard deviation $<2 \%$ ), while being easy, inexpensive and not as much of time consuming and can be rightfully useful for the assessment of Gatifloxacin in unlike dosage forms and dissolution studies [31].

\begin{tabular}{|c|c|c|c|c|c|c|c|}
\hline $\begin{array}{l}\text { Sr: } \\
\text { No }\end{array}$ & Drug & Method & Lambda Max & Linearity & LOD/LOQ & $\begin{array}{l}\text { Correlation coeffi- } \\
\text { cient }\left(R^{2}\right) \text { Value }\end{array}$ & Ref \\
\hline 1 & GA & $\begin{array}{l}\text { UV-Vis NIR } \\
\text { spectrophoto- } \\
\text { metric Method }\end{array}$ & $\begin{array}{l}\text { Phosphate buffer } \\
\text { (pH 7.4) -286nm } \\
\text { Hydrochloric acid } \\
\text { (pH1.2)- } 292 \mathrm{~nm}\end{array}$ & $\begin{array}{l}\text { Phosphate buffer (pH } \\
\text { 7.4) - 1-14 } \mu \mathrm{g} / \mathrm{mL} \text { Hy- } \\
\text { drochloric acid (pH1.2) } \\
\text { - 1-18 } \mu \mathrm{g} / \mathrm{mL}\end{array}$ & $\begin{array}{c}\text { LOD-PDP (pH 7.4) } \\
\text {-0.103 } \mu \mathrm{g} / \mathrm{mL} \text { Hydro- } \\
\text { chloric acid (pH1.2)- } \\
0.099 \mu \mathrm{g} / \mathrm{mL} \\
\text { LOQ- PDP (pH 7.4) } \\
\text {-0.312 } \mu \mathrm{g} / \mathrm{mL} \text { Hydro- } \\
\text { chloric acid (pH1.2)- } \\
0.300 \mu \mathrm{g} / \mathrm{mL}\end{array}$ & $\begin{array}{l}\text { Phosphate buffer (pH } \\
7.4)-0.999 \text { Hydrochlo- } \\
\text { ric acid (pH1.2)- } 0.999\end{array}$ & [31] \\
\hline 2 & $\begin{array}{c}\text { GA } \\
+ \\
\text { PRED }\end{array}$ & $\begin{array}{l}\text { First-order UV } \\
\text { derivative Spec- } \\
\text { trophotometric } \\
\text { method }\end{array}$ & $\begin{array}{l}\text { GA - } 348 \mathrm{~nm} \\
\text { PRED }-263 \mathrm{~nm}\end{array}$ & $\begin{array}{l}\text { GA - 3-21 } \mu \mathrm{g} / \mathrm{mL} \\
\text { PRED - 6-42 } \mu \mathrm{g} / \mathrm{mL}\end{array}$ & $\begin{array}{c}\text { GA - LOD- } 0.33 \mu \mathrm{g} / \\
\mathrm{mL} \text { LOQ- } 0.10 \mu \mathrm{g} / \mathrm{mL} \\
\text { PRED -LOD- } 0.16 \\
\mu \mathrm{g} / \mathrm{mL} \\
\text { LOQ- } 0.55 \mu \mathrm{g} / \mathrm{mL}\end{array}$ & $\begin{array}{c}\text { GA- } 0.999 \\
\text { PRED- } 0.999\end{array}$ & [32] \\
\hline 3 & $\begin{array}{c}\text { GA } \\
+ \\
\text { DFBA }\end{array}$ & $\begin{array}{l}\text { UV-Spectropho- } \\
\text { tometricQ-Ab- } \\
\text { sorption Ratio } \\
\quad \text { Method }\end{array}$ & $\begin{array}{c}\text { GA - } 241 \mathrm{~nm} \\
\text { DFBA- } 236 \mathrm{~nm}\end{array}$ & $\begin{array}{c}\mathrm{GA}-1-30 \mu \mathrm{g} / \mathrm{mL} \\
\mathrm{DFBA}-1-30 \mu \mathrm{g} / \mathrm{mL}\end{array}$ & $\begin{array}{c}\text { GA - LOD- } 0.06 \mu \mathrm{g} / \\
\mathrm{mL} \text { LOQ- } 0.20 \mu \mathrm{g} / \mathrm{mL} \\
\text { DFBA - } \\
\text { LOD- } 0.05 \mu \mathrm{g} / \mathrm{mL} \\
\text { LOQ- } 0.173 \mu \mathrm{g} / \mathrm{mL}\end{array}$ & $\begin{array}{c}\text { GA- } 0.998 \\
\text { DFBA - } 0.999\end{array}$ & [33] \\
\hline 4 & GA & $\begin{array}{l}\text { Area under } \\
\text { curve spectro- } \\
\text { photo-metric } \\
\text { method }\end{array}$ & $316-346 \mathrm{~nm}$ & $5-25 \mu \mathrm{g} / \mathrm{mL}$ & - & GA- 0999 & [34] \\
\hline 5 & GA & $\begin{array}{l}\text { Spectrophoto- } \\
\text { metric method }\end{array}$ & $\begin{array}{l}\text { BCG- } 415 \text { BCP- } 412 \\
\text { BPB- } 417 \text { ВТВ- } 414\end{array}$ & $\begin{array}{l}\text { BCG- 2-20 } \mu \mathrm{g} / \mathrm{mL} \\
\text { BCP- 2-14 } \mu \mathrm{g} / \mathrm{mL} \\
\text { BPB- 2-16 } \mu \mathrm{g} / \mathrm{mL} \\
\text { BTB- - 2-16 } \mu \mathrm{g} / \mathrm{mL}\end{array}$ & $\begin{array}{c}\text { BCG- LOD- } 0.218 \mu \mathrm{g} / \\
\text { mL LOQ- } 0.950 \mu \mathrm{g} / \\
\mathrm{mL} \\
\text { BCP- LOD- } 0.252 \mu \mathrm{g} / \\
\text { mL LOQ- } 0.840 \mu \mathrm{g} / \\
\mathrm{mL} \\
\text { BPB- LOD- } 0.312 \mu \mathrm{g} / \\
\text { mL LOQ- } 1.03 \mu \mathrm{g} / \mathrm{mL} \\
\text { BTB- LOD- } 0.232 \mu \mathrm{g} / \\
\text { mL LOQ- } 0.773 \mu \mathrm{g} / \\
\mathrm{mL}\end{array}$ & & [35] \\
\hline
\end{tabular}




\begin{tabular}{|c|c|c|c|c|c|c|c|}
\hline 6 & $\begin{array}{c}\mathrm{GA} \\
+ \\
\mathrm{AMB}\end{array}$ & $\begin{array}{l}\text { Spectrophoto- } \\
\text { metric method }\end{array}$ & $\begin{array}{l}\text { GA- } 286 \mathrm{~nm} \text { AMB- } \\
242 \mathrm{~nm}\end{array}$ & $\begin{array}{l}\text { GA- } 4-16 \mu \mathrm{g} / \mathrm{mL} \text { AMB- } \\
10-50 \mu \mathrm{g} / \mathrm{mL}\end{array}$ & $\begin{array}{l}\text { LOD-1.4 and } 1.9 \mu \mathrm{g} / \\
\mathrm{mL}\end{array}$ & $\begin{array}{c}\text { GA- } 0.9994 \text { AMB- } \\
0.9952\end{array}$ & [36] \\
\hline 7 & $\begin{array}{c}\text { GA } \\
+ \\
\mathrm{AM}\end{array}$ & $\begin{array}{l}\text { Spectrophoto- } \\
\text { metric methods }\end{array}$ & $\begin{array}{c}\text { GA- } 289 \mathrm{~nm} \text { AM- } \\
246 \mathrm{~nm}\end{array}$ & $\begin{array}{c}\text { GA- } 2-10 \mu \mathrm{g} / \mathrm{mLAM}-5 \\
-15 \mu \mathrm{g} / \mathrm{mL}\end{array}$ & - & GA- 0.9907 AM- 0.9896 & [37] \\
\hline 8 & $\begin{array}{c}\text { GA } \\
+ \\
\text { PRED }\end{array}$ & $\begin{array}{l}\text { Spectrophoto- } \\
\text { metric methods }\end{array}$ & $\begin{array}{l}\text { GA }-292 \mathrm{~nm} \\
\text { PRED - } 242 \mathrm{~nm}\end{array}$ & $\begin{array}{l}\mathrm{GA}-0.6-3 \mu \mathrm{g} / \mathrm{mL} \\
\text { PRED - } 2-10 \mu \mathrm{g} / \mathrm{mL}\end{array}$ & $\begin{array}{c}\text { GA - LOD- } 0.01388 \\
\mu \mathrm{g} / \mathrm{ml} \text { LOQ- } 0.04208 \\
\mu \mathrm{g} / \mathrm{ml} \\
\text { PRED - } \\
\text { LOD- } 0.02782 \mu \mathrm{g} / \mathrm{ml} \\
\text { LOQ- } 0.08432 \mu \mathrm{g} / \mathrm{ml}\end{array}$ & $\begin{array}{c}\text { GA- } 0.999 \\
\text { PRED- } 0.999\end{array}$ & [38] \\
\hline 9 & GA & $\begin{array}{l}\text { spectrophoto- } \\
\text { metric method }\end{array}$ & GA - $287 \mathrm{~nm}$ & 4 to $14 \mu \mathrm{g} / \mathrm{mL}$ & $\begin{array}{l}\text { GA - LOD- } 0.21 \mu \mathrm{g} / \mathrm{ml} \\
\text { LOQ- } 0.64 \mu \mathrm{g} / \mathrm{ml}\end{array}$ & GA- 0.999 & [39] \\
\hline 10 & GA & $\begin{array}{l}\text { spectrofluoro- } \\
\text { metric method }\end{array}$ & $\begin{array}{c}487 \mathrm{~nm} \text { after } \\
\text { excitati-on at } 290 \\
\mathrm{~nm}\end{array}$ & 10 to $100 \mathrm{ng} / \mathrm{ml}$ & $\begin{array}{c}\text { GA - LOD- } 0.2305 \\
\mathrm{ng} / \mathrm{ml} \text { LOQ- } 0.6986 \\
\mathrm{ng} / \mathrm{ml}\end{array}$ & GA- 0.9996 & [40] \\
\hline 11 & GA & $\begin{array}{l}\text { spectrofluoro- } \\
\text { metric method }\end{array}$ & $\begin{array}{c}470 \mathrm{~nm} \text { after } \\
\text { excitati-on at } 292 \\
\mathrm{~nm}\end{array}$ & $\begin{array}{l}\text { ASM- } 0.040-0.700 \mu \mathrm{g} / \\
\mathrm{mL} \\
\text { MEM- } 0.020-0.450 \mu \mathrm{g} / \\
\mathrm{mL}\end{array}$ & $\begin{array}{c}\text { ASM- LOD- } 10 \mu \mathrm{g} / \\
\mathrm{ml} \text { LOQ- } 30 \mu \mathrm{g} / \mathrm{ml} \\
0.6986 \mathrm{ng} / \mathrm{ml} \mathrm{MEM-} \\
\mathrm{LOD}-2 \mu \mathrm{g} / \mathrm{ml} 0.2305 \\
\mathrm{ng} / \mathrm{ml} \mathrm{LOQ}-6 \mu \mathrm{g} / \mathrm{ml}\end{array}$ & $\begin{array}{l}\text { ASM- } 0.9997 \\
\text { MEM- } 0.9998\end{array}$ & [41] \\
\hline
\end{tabular}

Table 3: Spectrophotometric and Spectrofluorimetric methods for estimation of GA alone and in combined dosage form.

Mangal Gahandule., et al. (2017) the aim of present work was to develop an accurate, simple and cost effective UV spectrophotometric method for estimation of gatifloxacin. This method was based on area under curve of UV spectrum between $316-346 \mathrm{~nm}$ and validation as per ICH guideline Q2 (R1). The method has followed linearity in the range of $5-25 \mu \mathrm{g} / \mathrm{ml}$. The value of correlation coefficient was 0.999 .Satiafactory value of percent relative standard deviation for the intraday and inter-day precision indicates that method was precise. Result of the recovery studies (102\%) shows accuracy of method. The developed technique can be used for schedule assessment of Gatifloxacin into bulk as well as dosage form. The developed method can be concluded as accurate, sensitive and precise and can be easily applied to the pharmaceutical formulation [34].

Alaa S. Amin., et al. (2017) Straightforward, rapid, and extractive spectrophotometric method were developed for the determination of Gatifloxacin (GA) into bulk as well as in to pharmaceutical dosage form. These methods are based on the formation of yellow ion-pair complexes between the basic nitrogen of the drug and three sulphonphthalein acid dyes, namely; bromocresol green (BCG), bromocresol purple (BCP), bromophenol blue (BPB) and bromothymol blue (BTB) in phthalate buffer pH 3.0, 3.4 and 3.2, using BCG, $\mathrm{BCP}$ and (BPB or BTB), respectively. The formed complexes were extracted with chloroform and measured at 415, 417, 412 and 414 $\mathrm{nm}$ for BCG, BPB, BCP and BTB, respectively. The analytical parameters and their effects on the reported systems are investigated. The reactions were extremely rapid at room temperature and the absorbance values remains unchanged at $48 \mathrm{~h}$ for all reactions. Beer's law was obeyed in the ranges 2.0-20, 2.0-14 and 2.0-16 $\mu \mathrm{gmL}^{-1}$ for BCG, BCP and (BPB or BTB), respectively. The composition of the ion pairs was found 1:1 by Job's method. Beer's law substantiation accuracy, precision, limits of detection, limits of quantification. The projected processes have been applied effectively for the investigation of the drug bulk form as well as its dosage form. The results 
were in good quality concurrence with those obtained by the administrators as well as reported methods [35].

\section{Estimation of GA in Combinations}

Sversut, R.A., et al. (2014) an uncomplicated technique used for instantaneous determination of Gatifloxacin as well as Prednisolone acetate into ophthalmic formulation was developed and validated by means of UV spectrophotometry. Gatifloxacin and Prednisolone acetate were enumerated by means of the first-order derivative of the UV spectra. The projected technique was validated according to the guiding principle of the International Conference on Harmonization as well as the Association of Official Analytical Chemists International. The measurements were completed having acetonitrile: water (70:30 v/v) at $348 \mathrm{~nm}$ used for Gatifloxacin as well as having Prednisolone acetateat $263 \mathrm{~nm}$. The calibration curves were linear having concentration assortment of 3-21 $\mu \mathrm{g}$ $\mathrm{mL}^{-1}$ used for Gatifloxacin as well as $6-42 \mu \mathrm{g} \mathrm{mL}^{-1}$ for Prednisolone acetate by means of Sandell's sensitivities of $0.349 \mu \mathrm{g} \mathrm{cm}^{-2}$ and $0.402 \mu \mathrm{g} \mathrm{cm}^{-2}$, correspondingly. The represent recovery and the limit of quantification for Gatifloxacin having $99.76 \pm 0.41 \%$ as well as $1.11 \mu \mathrm{g} \mathrm{mL}^{-1}$ and for Prednisolone acetate were $99.52 \pm 0.87 \%$ as well as $0.55 \mu \mathrm{g} \mathrm{mL}^{-1}$, correspondingly. The technique was precise, among a relative standard deviation of fewer than $2.50 \%$ for both drugs. For robustness, the feature analyzed did not extensively influence the quantification of Gatifloxacin and Prednisolone acetate. The results of the validated process did not be at variance notably from high-performance liquid chromatography (HPLC), which was up to that time developed and validated for the identical drugs. In this type, the technique was appropriate for regular analysis of Gatifloxacin and Prednisolone acetate within their combined dosage form in ophthalmic formulations [32].

Parth Patel., et al. (2001) two uncomplicated, susceptible, precise, accurate and inexpensive UV-Spectrophotometric technique developed for the quantitative evaluation of Difluprednate and Gatifloxacin into bulk and combined ophthalmic emulsion. The first technique concerned for determination of Difluprednate and Gatifloxacin by means of the Q-absorption ratio method, which involves the formation having Q-absorbance equation found at $236 \mathrm{~nm}$ (isoabsorptive point) as well as at $241 \mathrm{~nm}$, it is $\lambda$-max of Difluprednate. The linearity was achieved in the concentration assortment of 1-30 $\mathrm{ug} / \mathrm{mL}$ for both the drugs. The second technique involved determinations of these two drugs by means of the first-derivative spectrophotometric techniques were completed at $322.60 \mathrm{~nm}$ (ZCP of Difluprednate) used for Gatifloxacin as well as263.20 nm (ZCP of
Gatifloxacin) for Difluprednate. The linearity was achieved in the concentration range of $5-35 \mu \mathrm{g} / \mathrm{mL}$ intended for Difluprednate as well as $10-70 \mu \mathrm{g} / \mathrm{mL}$ for Gatifloxacin. These techniques were sequentially useful to pharmaceutical formulations because no interferences from the ophthalmic emulsion recipients were found. The appropriateness of these techniques for the quantitative estimation of the compounds was demonstrated by validation [33].

S. Lakshmana Prabu., et al. (2010) narrative, straightforward, sensitive, rapid spectrophotometric technique has been developed for instantaneous estimation of Gatifloxacin (GA) and Ambroxol hydrochloride (AMB). The technique implicated solving simultaneous equations based on extent of absorbance having two wavelengths at $286 \mathrm{~nm}$ as well asat $242 \mathrm{~nm}, \lambda$ max of GA and AMB in that order. Beer's law was obeyed in the concentration range of $4-16 \mu \mathrm{g} / \mathrm{ml}$ and $10-50 \mu \mathrm{g} / \mathrm{ml}$ for GA and AMB respectively. The method was validated for accuracy, precision and recovery studies. Statistical analysis proved the method was precise, reproducible, selective, specific, and accurate for analysis of GA and AMB. The wide linearity range, sensitivity, accuracy, and simple procedure imply that the proposed technique demonstrated to be appropriate for routine analysis and quality control assays of tablets [36].

B.Prathap, G. Nagarajan., et al. (2011)a simple, fast and precise simultaneous estimation method using Vierodt's method has been developed for the simultaneous determination of Gatifloxacin and Ambroxol hydrochloride in pure and combined tablet dosage form. Shimadzu UV-1700 instrument was used and $\lambda$ max of Gatifloxacin and Ambroxol hydrochloride was found to be 289 and $246 \mathrm{~nm}$, respectively using methanol and $0.1 \mathrm{M}$ sodium hydroxide in the ratio of 8:2. Gatifloxacin and Ambroxol hydrochloride were found to be linear in the concentration of $2-10 \mu \mathrm{g} / \mathrm{ml}$ and $5-15 \mu \mathrm{g} / \mathrm{ml}$, respectively at their wavelengths. Amount found for Gatifloxacin and Ambroxol hydrochloride was found to be 397.61 and $73.91 \mathrm{mg} /$ tablet, respectively. Percentage recovery range was found to be within 99.45-100.3\% for Gatifloxacin and 99.73-103.42\% for Ambroxol hydrochloride. The percentage RSD was found to be lower than $2 \%$ proves that the method is precise. The application of simultaneous equation method by UV spectroscopy can be employed for the estimation of Gatifloxacin and Ambroxol hydrochloride for routine analysis for a combination containing these two components in pure and tablet dosage forms [37].

Jugalkishor Vijay Bhandari., et al. (2018) UV spectrophotometric technique has been developed as well as validated meant for the determination of Gatifloxacin and Prednisolone Acetate into bulk 
and eye drop. The $\lambda$ max of Gatifloxacin and Prednisolone Acetate were found to be $292 \mathrm{~nm}$ and $242 \mathrm{~nm}$, respectively, in methanol. Beer`s law was complied through the conc. range of $0.6-3 \mu \mathrm{g} / \mathrm{ml}$ and $2-10 \mu \mathrm{g} / \mathrm{ml}$ with correlation coefficient of 0.999 and 0.999 for Gatifloxacin and Prednisolone Acetate, respectively. The result of analysis has been validated as per the ICH guidelines. The developed method is simple, selective and reproducible and can be used for routine analysis of formulations containing Gatifloxacin and Prednisolone Acetate [38].

\section{Spectrofluorometric Methods}

Fathy M.M. Salama., et al. (2018) a extremely correct and precise Spectrofluorimetric method was recognized for quantitation of Gatifloxacin in pure substance, pharmaceutical formulations as well as in the continuation of its oxidative degradation product. The emission was recorded at $487 \mathrm{~nm}$ after the excitation at $290 \mathrm{~nm}$. Using micelle, sodium dodecyl sulphate (SDS), enhanced fluorescence intensity of Gatifloxacin-SDS complex. The optimization of numerous experimental conditions was carried out. The improved emission showed a suitable linear correlation between derivative synchronous fluorescence power and concentration of Gatifloxacin over the range of 10 to $100 \mathrm{ng} / \mathrm{mL}$ with a determination coefficient equals 0.9996 . Studying cytotoxicity and antimicrobial susceptibility for oxidative degradation product of Gatifloxacin was carried out using Gatifloxacin as a control. In comparison, the proposed method presented a superior sensitivity and enhanced stability over the reported method [40].

Juan Antonio Ocana., et al. (2018) a Spectrofluorimetric method to determine gatifloxacin has been developed and applied to the quantification of this fluoroquinolone in spiked human urine and serum. The native fluorescence of Gatifloxacin allow the determination of $0.040-0.700 \mu \mathrm{gmL}^{-1}$ of this molecule in aqueous solution containing acetic acid-sodium acetate buffer ( $\mathrm{pH} 3.5$ ), with $\lambda_{\mathrm{exc}}=$ $292 \mathrm{~nm}$ and $\lambda_{\text {em }}=484 \mathrm{~nm}$. Micelle-enhanced fluorescence led to $75 \%$ higher analytical signals in presence of $12 \mathrm{mM}$ sodium dodecyl sulphate, which allow the determination of $0.020-0.450 \mu \mathrm{gmL}^{-1}$ fluoroquinolone with $\lambda_{\text {exc }}=292 \mathrm{~nm}$ and $\lambda_{\mathrm{em}}=470 \mathrm{~nm}$. Both methods were successfully applied to gatifloxacin determination in spiked human urine and serum [41].

\section{Electrochemical methods}

In the last decade, bio sensing has rapidly evolved and become one of the most important research priorities in analytical chemistry and chemical sensors. Numerous techniques have been re- ported for the fabrication of the biosensor interface and for constructing whole bio-sensing platforms. The most common modes of transduction include fluorescence, surface plasmon resonance, photoluminescence, surface-enhanced Raman scattering, electrochemiluminescence, photo electrochemistry, and electrochemistry. Amongst these techniques, electrochemical sensors have attracted considerable interest of analysts due to advantages such as rapid sample-to-answer time, high sensitivity, low cost and potential translation in point-of-care settings.

Zhiming Jiang., et al. (2016) constructed a new electrochemical sensor for Gatifloxacin based on one-pot electro-polymerization of $\beta$-cyclodextrin ( $\beta$-CD) and reduced-graphene oxide (rGO) modified glassy carbon electrode (GCE) ( $\beta$-CD/rGO/GCE) was built for the first time. Scanning electron microscope (SEM) image and Infrared spectroscopy (IR) show that polymer of $\beta$-cyclodextrin and reduced graphene oxide (rGO) has been successfully modified on electrode. The electrochemical properties of this polymer were characterized by electrochemical impedance spectroscopy (EIS) and cyclic voltammetry (CV). The optimization of the electro-polymerized cycle, the $\mathrm{pH}$ of supporting electrolyte and the accumulation potential and time were discussed in details. Underneath most favourable circumstances, the degree of difference pulse voltammogram (DPV) demonstrated the oxidation peak currents were linearly proportional to Gatifloxacin concentrations into the ranges of $0.05 \mu \mathrm{M}$ to $150 \mu \mathrm{M}$ with sensitivity of $0.33 \mu \mathrm{A} \mu \mathrm{M}-1$. This electrochemical sensor had a low detection limit of $0.02 \mu \mathrm{M}(\mathrm{S} / \mathrm{N}=$ 3). Moreover, this proposed sensor exhibited good reproducibility, long-term stability and fast current response. To further study the practical applicability of the proposed sensor, the modified electrode was successfully applied to detect Gatifloxacin in tablets and human urine samples [42].

Jian Y., et al. (2012) development of an electrochemical immunoassay to detect Gatifloxacin (GA) residue in swine urine, an electrochemical immunoassay was established. An indirect competitive immunoassay was developed, in which the coating antigen is immobilized in an enzyme linked immunosorbent assay (ELISA) plate and GA residue from the sample competes with the limited binding sites in added anti-GA antibody. Horseradish peroxidase (HRP) conjugated to goat anti-rabbit IgG was used as the enzymatic label. A carbon fibre working electrode was constructed and current signals were detected by using hydrogen peroxide as a substrate and hydroquinone as an electrochemical mediator. The electrochemical immunoassay was evaluated by analysis of GAT in buffer or swine 
urine and an average value of half inhibition concentration (IC50) of $8.9 \mathrm{ng} / \mathrm{ml}$ was obtained. Excellent specificity of the antibody was achieved with little cross-reaction with Lomefloxacin (3.0\%), ciprofloxacin (3.0\%), and ofloxacin (1.9\%) among commonly used (fluoro) quinolones. In conclusion, the immunoassay system developed in this research can be used as a rapid, powerful and on-site analytical tool to detect GAT residue in foods and food products [43].

Pradeep Kumar Brahman., et al. (2012) the electrochemical oxidation of an antibacterial drug, gatifloxacin (GA), at multi-walled carbon nano-tube paste electrode was studied employing cyclic and differential pulsevoltammetry methods. The effects of scan rate, $\mathrm{pH}$, different electrolytes, and pulse amplitude and accumulation time on electrochemical behaviour of GA were investigated. GA shows a well-defined oxidation peak at $+1.05 \mathrm{~V}$ in acetate buffer of pH $5.0 \pm 0.01$. Underneath optimized circumstances, the peak current is linear over the concentration range $2.13 \times 10^{-5}-1.7 \times 10^{-4}$ $\mathrm{m}$ through detection limit of $4.5 \times 10-9 \mathrm{~m}$. The applicability of the proposed method is further extended to in vitro determination of the drug in biological fluids. Differential pulse voltammetry and UV-VIS absorption techniques were employed to probe the interaction between GA and calf thymus DNA. The addition of ds-DNA to the analyte containing GA results in a decrease of the peak current and a positive shift of the peak potential of GA in differential pulse voltammetry analysis, indicating the dominance of the intercalating interaction. The spectroscopic data also confirm the interaction between GA and ds-DNA. The combining constant $(\beta)$ and combining number $(\mathrm{m})$ of GA-mDNA were also determined [44].

Fenfen Zhang., et al. (2013) initiate new cysteic acid customized carbon paste electrode (cysteic acid/CPE)lying on electrochemical oxidation of L-cysteine was urbanized to simultaneously determine of Ofloxacin as well as Gatifloxacin within the occurrence of sodium dodecyl benzene sulfonate (SDBS). Fourier transform infrared spectra (FTIR) pointed out that L-cysteine was oxidated to cysteic acid. Electrochemical impedance spectroscopy (EIS) and cyclic voltammogram (CV) designated so as to cysteic acid was effectively modified on electrode. The bulky peak separation (116 $\mathrm{mV}$ ) among Ofloxacin and Gatifloxacin was achieved on cysteic acid or CPE while merely one oxidation peak was originate on bare electrode. And the peak currents enlarged 5 times measure up to bare electrode. Furthermore, the current might be auxiliary improved in the existence of an anionic surfactant, sodium dodecyl benzene sulfonate. The degree of difference pulse voltammogram (DPV) demonstrated that the oxidation peak currents were linearly com- parative to their concentrations into the range of $0.06-10 \mu \mathrm{M}$ for Ofloxacin and $0.02-200 \mu \mathrm{M}$ for gatifloxacin, as well as the detection limits of Ofloxacin and Gatifloxacin were $0.02 \mu \mathrm{M}$ and $0.01 \mu \mathrm{M}$ $(\mathrm{S} / \mathrm{N}=3)$, correspondingly. This projected technique was effectively useful to determine Ofloxacin and Gatifloxacin in pharmaceutical formulations as well as in human serum samples [45].

\section{HPTLC methods}

Sanjay K. Motwani., et al. (2006) straightforward, susceptible, selective and stability indicating high-performance thin-layer chromatographic technique used for determination of Gatifloxacin not in bulk drug but also in polymeric nano-particles was developed and validated for same as per the International Conference on Harmonization (ICH) guidelines. The technique utilized thinlayer chromatography (TLC) aluminium plates permeated with silica gel 60F-254 like the stationary phase and the mobile phase containedn-propanol: concentrated ammonia solution: methanol (5:0.9:1, v/v/v). This solvent system was established to provide solid spots for Gatifloxacin (Rf value of $0.60 \pm 0.02$ ). Densitometric assessment of Gatifloxacin was accepted having absorbance mode at $292 \mathrm{~nm}$. The linear regression investigation information for the calibration plots demonstrated good linear relationship through $r=0.9953$ having the concentration range of 400-1200 ng/ spot. The mean value ( \pm S.D.) of slope and intercept were $9.66 \pm 0.05$ and $956.33 \pm 27.67$, respectively. The technique was validated for precision, ruggedness, accuracy, and recovery. The limits of detection as well as quantitation were found to be 2.7 and $8.2 \mathrm{ng} / \mathrm{spot}$, in that order. Gatifloxacin was subject to acid as well as alkali hydrolysis, photo degradation, oxidation and dry heat treatment. The drug go through degradation beneath acidic as well as basic conditions and upon wet and dry heat treatment. The degraded compounds were well separated among the pure drug. The numerical assessment display that the developed process for Gatifloxacin as bulk drug and from polymeric nanoparticles is reproducible as well as selective. The technique possibly will successfully separate the drug among its degradation products, be able to employed as stability-indicating one [46].

N. Satheeshkumar., et al. (2006) a straightforward and sensitive high-performance thin-layer chromatography (HPTLC) technique was intended for the quantitative assessment of Gatifloxacin as well as Ornidazole in pharmaceutical formulation. Gatifloxacin and Ornidazole were chromatographed on silica Gel 60 F254 TLC plate having n-butanol: ammonia: methanol (8:1.5:1 v/v) mobile phase in addition to detected at $302 \mathrm{~nm}$ with a Camag TLC Scanner 3. The Rf value for Gatifloxacin and Ornidazole was observed as $0.21 \pm$ 
0.02 and $0.76 \pm 0.04$, correspondingly. The linearity of Gatifloxacin and Ornidazole having in the range of $100-500 \mathrm{ng} / \mathrm{spot}$ and 250 $-1250 \mathrm{ng} / \mathrm{spot}$, correspondingly. The LOQ for Gatifloxacin was obtained $40 \mathrm{ng} / \mathrm{spot}$ and for Ornidazole was obtained $100 \mathrm{ng} / \mathrm{spot}$. The projected technique was useful for the determination of Gatifloxacin and Ornidazole in combined dosage forms [47].



Figure 3: Overview of analytical methods for estimation of Gatifloxacin in biological and pharmaceutical samples.

\section{Conclusion}

In conclusion, abroad ranges of techniques are available for the analysis of Gatifloxacin in biological samples and pharmaceutical formulations. The analysis of the published data revealed that the HPLC was extensively used for the determination of Gatifloxacin in various matrices like plasma, serum and urine. For determination of Gatifloxacin in biological samples, were commend the HPLCMS/MS method, since this method combines the HPLC separation ability with MS sensitivity and selectivity, allowing the unambiguous identification of Gatifloxacin and its metabolites. For analysis of Gatifloxacin in pharmaceuticals, HPLC with UV detection is applicable because this method provides accurate results and low cost compared to more advanced detection techniques. This review carried out an overview of the current state-of-art analytical methods for the determination of Gatifloxacin.

\section{Bibliography}

1. DN Fish and DS North. "Gatifloxacin, an advanced 8-methoxy fluoroquinolone”. Pharmacotherapy 21 (2001): 35-59.

2. Mignot A., et al. "Oral bioavailability of gatifloxacin in healthy volunteers under fasting and fed conditions". Chemotherapy 48.3 (2002): 111-115.

3. Blondeau JM. "Gatifloxacin: a new fluoroquinolone". Expert Opine Investing Drugs 9.8 (2000): 1877-95.
4. Grasela DM. "Clinical pharmacology of gatifloxacin, a new fluoroquinolone”. Clinical Infectious Diseases 31 (2000): S51-58.

5. Yun Chai., et al. "Synthesis and in vitro antibacterial activity of a series of novel gatifloxacin Derivatives". European Journal of Medicinal Chemistry 46 (2011): 4267-4273.

6. CY Hong., et al. Bioorganic and Medicinal Chemistry Letters 8 (1998): 221-226.

7. V Cecchetti., et al. Journal of Medicinal Chemistry 39 (1996): 436-445.

8. Dennis M Grasela. "Clinical Pharmacology of Gatifloxacin, a New Fluoroquinolone”. Clinical Infectious Diseases 31 (2000): S51-58.

9. Tiwari G and Tiwari R. "Bioanalytical method validation: An updated review". Pharm Methods 1 (2010): 25-38.

10. Jacqueline MR., et al. "High performance liquid chromatography (HPLC): Principles and applications". Techniques and Instrumentation in Analytical Chemistry (1997): 37-59.

11. Aljuffali IA., et al. "Development and validation of stability-indicating high performance liquid chromatography method to analyze Gatifloxacin in bulk drug and pharmaceutical preparations". Saudi Pharmaceutical Journal (2014).

12. B Patel., et al. "Development and Validation of HPLC Method for the Simultaneous Estimation of Satranidazole and Gatifloxacin in Tablet Dosage Form". International Journal of Chem Tech Research 1 (3) 587-590.

13. Petha NM., et al. "Development and Validation of High Performance Liquid Chromatography method for analysis of Gatifloxacin and its Impurity Pharma Tutor". 5.3 (2017) 37-41.

14. P Nagaraju., et al. "Development and Validation of New RPHPLC Method For Simultaneous Estimation of Gatifloxacin and Difluprednate In Pharmaceutical Dosage Forms". International Journal of Pharmaceutical and Chemical Sciences 4 (2015): 2277-5005.

15. Ankit Agarwal., et al. "Method Development and its Validation for Quantitative Simultaneous Determination of Dexamethasone and Gatifloxacin in Ophthalmic Solution by RP-HPLC". International Journal of Medicine and Pharmaceutical Research 1 (2013): 139-144.

16. Shahed Mirza., et al. "Simultaneous Determination of Gatifloxacin and Ambroxol Hydrochloride From Tablet Dosage Form Using Reverse-phase High Performance Liquid Chromatography". Chinese Journal of Chromatography 26.3 (2008): 358361. 
17. Maria Ines RM., et al. "Quantitative Determination of Gatifloxacin, Levofloxacin, Lomefloxacin and Pefloxacin Fluoroquinolonic Antibiotics In Pharmaceutical Preparations By High-Performance Liquid Chromatography". Journal of Pharmaceutical and Biomedical Analysis 40 (2006): 179-184.

18. Ashok Kumar Bera., et al. "Simple Isocratic Rp-HPLC Method Development and Validation For Estimation of Gatifloxacin In Tablet Dosage Form". International Journal of Pharmaceutical Sciences and Research 5 (2014): 3741-3745.

19. Sonali Paramane., et al. "Simultaneous RP-HPLC Estimation of Gatifloxacin and Ornidazole in Tablet Dosage Form". Indian Journal of Pharmaceutical Sciences 69 (2007): 525-528.

20. Syed Naeem Razzaq., et al. "Development and Validation of Liquid Chromatographic Method for Gatifloxacin and Ketorolac Tromethamine In Combined Dosage Form". Journal of Liquid Chromatography and Related Technologies 35 (2013): 651-661.

21. Syed Naeem Razzaq., et al. "Stability indicating RP-HPLC method for simultaneous determination of gatifloxacin and dexamethasone in binary combination". Brazilian Journal of Pharmaceutical Sciences 53 (2017): 15177.

22. K Morner., et al. "Determination of Gatifloxacin in Human Serum and Urine by HPLC". Chromatographia Supplement 52 (2000): 105-107.

23. Leandro Tasso., et al. "High performance liquid chromatography for quantification of gatifloxacinin rat plasma following automated on-line solid phase extraction". Journal of Pharmaceutical and Biomedical Analysis 44 (2007): 205-210.

24. Angelo Spadaro and Maria Pappalardo. "Preclinical Pharmacokinetic Evaluation of Gatifloxacin Mucoadhesive Formulations in Rabbit Eye using HPLC". Journal of Pharmaceutical Sciences and Research 7.12 (2015) 1109-1113.

25. Joana Sousaa., et al. "First Liquid Chromatography Method for The Simultaneous Determination of Levofloxacin, Pazufloxacin, Gatifloxacin, Moxifloxacin and Trovafloxacin In Human Plasma". Journal of Chromatography B 930 (2013) 104- 111.

26. ML Salazar Cavazos., et al. "Determination of Gatifloxacin in Semen by HPLC with Diode-Array and Fluorescence Detection". Chromatographia 63 (2006): 605-608.

27. Deli Xiao., et al. "Development of novel molecularly imprinted magnetic solid-phase extraction materials based on magnetic carbon nanotubes and their application for the determination of gatifloxacin in serum samples coupled with high performance liquid chromatography". Journal of Chromatography (2013): 44-53.
28. Saleh Al Dgither., et al. "Development and validation of An HPLC Method for the Determination of Gatifloxacin Stability in Human Plasma". Journal of Pharmaceutical and Biomedical Analysis 41 (2006): 251-255.

29. Marieta LC., et al. "Detection in UV-visible spectrophotometry: Detectors, detection systems, and detection strategies". Measurement 135 (2009): 896-904.

30. BM Tissue. in Characterization of Materials, ed. E. N. Kaufmann, John Wiley \& Sons, Inc., (2012).

31. K Venugopal., et al. "New, simple and validated UV-spectrophotometric methods for the estimation of gatifloxacin in bulk and formulations K. Venugopal, R.N. Saha/Farmaco 60 (2005): 906-912.

32. Sversut RA., et al. "Simultaneous determination of gatifloxacin and prednisolone acetate in ophthalmic formulation using first-order UV derivative spectroscopy". Arabian Journal of Chemistry (2014).

33. Parth Patel., et al. "Development and Validation Of Analytical Methods For Simultaneous Estimation of Difluprednate and Gatifloxacin In Ophthalmic Emulsion By Uv- Visible Spectroscopy". International Journal of Pharmaceutical Science 3 (2001): 01-10.

34. Mangal Gahandule., et al. "Estimation of gatifloxacin in pharmaceutical formulation by area under curve spectrophotometric method". International Journal of Chemistry Studies 1 (2017): 39-43.

35. Alaa S Amin., et al. "Spectrophotometric determination of gatifloxacin in pure form and in pharmaceutical formulation". Spectrochimica Acta Part A 67 (2007): 1306-1312.

36. S Lakshmana Prabu., et al. "Simultaneous Estimation of Gatifloxacin and Ambroxol Hydrochloride By Uv-Spectrophotometry". International Journal of Pharmaceutical Sciences Review and Research 3 (2010): 123-126.

37. B Prathap., et al. "Spectrophotometric method for simultaneous estimation of Gatifloxacin and Ambroxol Hydrochloride in tablet dosage form". Der Pharmacia Lettre 3 (2011): 62-68.

38. Jugalkishor Vijay Bhandari., et al. "Spectrophotometric Method Development and Validation for Estimation of Gatifloxacin and Prednisolone Acetate in Bulk and Eye Drop". International Journal for Pharmaceutical Research Scholars 7 (2018): 107112.

39. Cristiani Capistrano Gonçalves de Oliveira Lopes and Hérida Regina Nunes Salgado. "Performance characteristics of bioassay UV-spectrophotometry and high perfomance liquid chromatographic determination of gatifloxacin in tablets". Quimica Nova 31 (2008): 1831-1835. 
40. Fathy MM., et al. "First derivative synchronous fluorescence spectroscopy for the determination of Gatifloxacin in presence of its oxidative degradation product: Application to pharmaceutical preparation". Saa (2018).

41. Juan Antonio Ocana., et al. "Spectrofluorimetric and micelleenhanced spectrofluorimetric determination of gatifloxacin in human urine and serum". Journal of Pharmaceutical and Biomedical Analysis 37 (2005): 327-332.

42. Zhiming Jiang., et al. "Electrochemical sensor based on electropolymerization of $\beta$-cyclodextrin and reduced-graphene oxide on glassy carbonelectrode for determination of gatifloxacin". Sensors and Actuators B 228 (2016): 59-65.

43. Jian YI., et al. "Development of an electrochemical immunoassay for detection of Gatifloxacin in swine urine". J Zhejiang Univ-Sci B (Biomed and Biotechnology) 13 (2012): 118-125.

44. Pradeep Kumar Brahman., et al. "Electrochemical behavior of gatifl oxacin at multi-walled carbon nanotube paste electrode and its interaction with DNA". Reviews in Analytical Chemistry 31 (2012): 83-92.

45. Fenfen Zhang., et al. "Simultaneous determination of ofloxacin and gatifloxacin on cysteic acid modified electrode in the presence of sodium dodecyl benzene sulfonate". Bioelectrochemistry 89 (2013): 42-49.

46. Sanjay K Motwani., et al. "Stability indicating high-performance thin-layer chromatographic determination of gatifloxacin as bulk drug and from polymeric nanoparticles". Analytica Chimica Acta 576 (2006): 253-260.

47. Bhanubhai N SUHAGIA., et al. "Determination of Gatifloxacin and Ornidazole in Tablet Dosage Forms by High-Performance Thin-Layer Chromatography". Aanalytical Sciences 22 (2006): 743-745.

\section{Volume 3 Issue 6 June 2019}

(c) All rights are reserved by Pritam S Jain., et al. 